DOI: https://doi.org/10.32839/2304-5809/2020-4-80-32

УДК 37.09-054.62:811.161.1

Лисенко І.О., Вальченко І.В., Плотнікова Т.О., Сергійчук Л.В., Соколова Г.П. Харківський національний університет міського господарства імені О.М. Бекетова

\title{
ГРА ЯК ЗАСІБ ФОРМУВАННЯ КОМУНІКАТИВНОЇ КОМПЕТЕНЦЇ̈ НА ЗАНЯТТЯХ З УКРАЇНСЬКОЇ МОВИ ЯК ІНОЗЕМНОЇ
}

Анотація. У статті розглянуто проблему формування комунікативної компетенції іноземних студентів у процесі ігрової діяльності. Розкрито важливість використання навчальних ігор на заняттях з української мови як іноземної та їх вплив на розвиток комунікативної компетенції. Акцентовано увагу на ролі гри в процесі формування комунікативних навичок іноземних студентів з початковим рівнем володіння мовою. Проаналізовано вплив використання ігор для реалізації важливих завдань із формування комунікативних навичок студентів-іноземців. Охарактеризовано значимість забезпечення ігрового характеру навчально-виховного процесу. Запропоновано приклади навчальних ігор. Зроблено висновок про можливість успішного формування комунікативних навичок іноземних студентів у процесі навчання засобами комунікативних ігор.

Ключові слова: ігрові методи навчання, комунікативна компетенція.

Lysenko Iryna, Valchenko Inna, Plotnikova Tetiana, Sergiychuk Liubov, Sokolova Galina O.M. Beketov National University of Urban Economy in Kharkiv

\section{THE GAME AS A MEANS OF FORMING COMMUNICATION COMPETENCE IN UKRAINE AS A FOREIGN LANGUAGE}

Summary. The article deals with theoretical and practical aspects of the process of formation of communicative competence of foreign students in the process of playing activities. The analysis of the current state of the issue of the formation of communicative competence and the use of game technologies during the study of Ukrainian as a foreign language is made. The importance of using educational games in the Ukrainian language classes as a foreign language and their influence on the development of communicative competence is revealed. Classifications of educational language games, their functions and meanings, methods of conducting are given. The influence of using games for realization of important tasks on the formation of communication skills of foreign students is analyzed. Particular attention is paid to solving the problem of successful communication with native speakers. The importance of ensuring the game character of the educational process is characterized. Emphasis is placed on the role of play in the process of forming the communication skills of foreign students with an initial level of command of the language. Examples of training games for practical training are offered. Examples of role-playing games using illustrated diagrams, itineraries, and maps that are needed in real communication are provided. Visualization is one of the keys to memory, making it easy to remember new vocabulary and new grammar rules. The purpose of the games offered is successful communication through a foreign language. It is established that important skills are formed during the game. They will influence their adaptation in the language environment and the development of students' creative potential. The conclusion is made about the effectiveness of the use of game methods in order to develop the communication skills of foreign students in the learning process. Play methods are a non-standard form of pedagogical interaction. They contribute to the formation of a socially active, communicative personality. They are also a means of successfully developing the communication skills of future professionals.

Keywords: game teaching methods, communicative competence.

$\prod^{\circ}$ остановка проблеми. Сьогодні освітня робота 3 іноземними студентами у вищих навчальних закладах спрямована на забезпечення умов, які надають їм широкі можливості для фрормування соціально-активної особистості. 3 огляду на такий підхід особливої значимості набуває проблема успішної комунікації студентів у соціумі.

Одним із головних завдань освіти, як зазначено в Законі України «Про вищу освіту», є підготовка конкурентоспроможного людського капіталу для високотехнологічного та інноваційного розвитку країни, самореалізації особистості, забезпечення потреб суспільства, ринку праці та держави у квалірікованих фрахівцях [11].

Основи комунікативної компетенції іноземних студентів закладаються на початковому етапі вивчення мови й визначають напрямок їх успішної комунікації та адаптації в соціумі.
Аналіз останніх досліджень і публікацій щодо формування комунікативної компетенції у студентів засобами гри формуе уявлення про сучасний стан розкриття питання 3 даної теми та свідчить про те, що питання формування комунікативної компетенції іноземних студентів у процесі ігрової діяльності дедалі більше набуває особливої актуальності.

Проблемам гри приділяли увагу такі вчені та науковці як К. Гроос [7], Л. Виготський [3], Д. Ельконін [4], Ш. Амонашвілі, В. Шаталов. Зокрема, К. Гроос вважав, що гра є первинною фрормою залучення людини до соціуму [7].

На сьогодні у педагогіщі вважається, що фрормування комунікативної компетенції засобами гри сприяе розвитку особистості, успішній адаптації у соціумі, активізації мислення й поведінки студента, високому ступеню задіяності у на- 
вчальному процесі, самостійності у прийнятті рішення.

Сучасний стан питання використання мовних ігор та їх роль у формуванні комунікативної компетенції під час вивчення мов досліджують науковці Л. Азаріна, А. Акішина, Н. П'яст, О. Полінська, О. Мармаза.

Виділення не вирішених раніше частин загальної проблеми. Визначення багатьох понять комунікативної компетенції, фрормування їі як багатогранної характеристики об'єктивною мірою свідчить про існування ряду невирішених питань, що у свою чергу вимагає проведення подальших досліджень щодо питання формування комунікативної компетенції засобами гри у іноземних студентів під час вивчення української мови. Підвищений інтерес викликає питання пошуків нестандартних засобів навчання та фрорм педагогічної взаємодії.

Мета статті. Головною метою ціеї роботи $€$ розглянути теоретичні та практичні аспекти процесу формування комунікативної компетенції іноземних студентів засобами гри та запропонувати ефрективні засоби його реалізації.

Виклад основного матеріалу дослідження 3 повним обгрунтуванням отриманих наукових результатів. В умовах розвитку сучасного суспільства актуальним є впровадження в практику роботи у вищих навчальних закладах оновленої моделі організації навчання, яка орієнтує викладачів на цілісний підхід до формування особистості, мовленневої компетентності студента. У науковій літературі вживаються і поняття «компетенція», і поняття «компетентність». Ця схожість не є випадковою, адже ці категорії походять 3 одного джерела: 3 латинської мови competentia - узгодженість, відповідність, а competo - відповідати бути годящим, здатним.

A. Хуторський пропонуе використовувати ці поняття паралельно, але вкладати в них різний сенс. Компетенція - це сукупність взаємопов'язаних якостей особистості (знань, умінь, способів діяльності), які $є$ заданими до відповідного кола предметів і процесів та необхідними для якісної продуктивної дії по відношенню до них. Компетентність - це володіння людиною відповідною компетенцією, що містить її особистісне ставлення до предмета діяльності. Тобто компетенцію, за А. Хуторським, слід розуміти як задану вимогу, норму освітньої підготовки студента, а компетентність - як його реально сорормовані особистісні якості та мінімальний досвід діяльності [13, с. 24].

У дослідженнях С. Срмоленко, компетенція, в широкому їі розумінні, трактується як якість особистості, яка володіе певними знаннями в певній галузі та вміє їх застосувати на практиці, забезпечувати успішну діяльність. До комунікативних компетенцій залучають вміння слухати (розуміти мовлення у звуковому оформленні), уміння говорити (висловлюватися в усній фрормі), уміння читати (розуміти мовлення в його графрічному оформленні), уміння писати (висловлювати думки в письмовій формі) [5, с. 42].

Комунікативна компетентність - це категорія, яка своїм змістом зорієнтована безпосередньо на практичний аспект навчання мови. Більше того, вона визначає домінуючу спрямова- ність навчального процесу. Ця категорія характеризуеться поліфракторністю своїх складників, що утруднює теорію її осмислення і не дає змоги дійти висновку щодо єдиного визначення цього поняття. Уміння, що використовує людина в процесі своєї мовленневої діяльності, називаються комунікативними вміннями, що грунтуються на чіткому усвідомленні діï, її складу, структури [10, c. 47].

Комунікативний підхід, прийнятий у сучасній вітчизняній методиці як провідний принцип, має на увазі придбання студентами-іноземцями здатності практичного використання української мови в реальних ситуаціях спілкування. Це стає можливим лише на основі дійсного мовного розвитку. Студент-іноземець змушений вступати в комунікацію на чужій для нього мові 3 першого дня його перебування в нерідній країні. Це $є$ величезною проблемою для іноземців, особливо якщо вони абсолютно не знають мову ціеї країни. Таким чином, викладач повинен полегшити вивчення нерідної мови, зробити доступною комунікацію на цій мові, зняти стрес від зустрічі 3 незнайомою дійсністю.

Відповідно до принципів комунікативного навчання, володіння мовою - це уміння вирішувати комунікативні завдання мовними засобами [2, c. 26].

Узагальнюючи наведені вище твердження, можна вважати, що під комунікативною компетенцією розуміються знання, вміння та навички, необхідні для розв'язання комунікативних завдань мовними засобами: розуміти мовлення і в звуковому, і в графрічному офрормленні, висловлюватися в усній формі і висловлювати думки в письмовій формі, забезпечуючи успішну діяльність.

Як один із ефективних засобів формування комунікативних навичок у студентів $є$ ігри. Педагогічна гра як форма навчального заняття має особливу суттєву ознаку - чітко поставлену мету навчання та відповідний прогнозований результат. Ігрові технології використовуеться у навчанні протягом усіеї історії вивчення мов, дозволяючи відносно легко застосовувати сформовані мовленневі навички, самостійно вирішувати ті чи інші завдання. Ігрові методи навчання займають важливе місце у процесі формування комунікативної компетенції іноземних студентів, розвитку їх творчого потенціалу. Студент під час гри пізнає свої можливості, вчиться їх оцінювати, відчуває різні емоції. Таким чином гра виступає як засіб спілкування. Суть гри як виду спілкування полягає в тому, що знання отримуються внаслідок постійного діалогу, полілогу.

Гра є однією з форм навчальної діяльності, що викликае потребу говорити, вирішуе проблему мотивації навчальної діяльності. Позитивною стороною гри $є$ те, що вона $є$ творчою за своїм характером, активізуе мисленневу діяльність студентів і сприяє розвитку творчого ставлення до мови [2, с. 219].

Дослідниця О. Акішина пропонуе таку загальну класифрікацію ігор: ігри настільні (доміно, карти, лото); ігри-змагання («Хто більше?», «Хто швидше?»), ігри з використанням схем, планів, карт (планування маршруту та подорожі; розповіді про місто); ігри з використанням предметів, іграшок (м'яч, пісочний годинник, секундомір); 
ігри-вправи «сніжна грудка», «коло в колі» та ін.; «лом» - розрізані тексти які необхідно зібрати; ігри-загадки: «Що це таке?», «Хто це?», «Про що ця розповідь?»; фольклорні ігри-забави, ігри-рухи (гімнастичні команди, інші команди для руху; конкурси, олімпіади, диспути, дискусії; ігри для розвитку здібностей учнів, пам'яті, уваги; ігридраматизації, скетчі, рольові ігри [2, с. 219]. Також пропонує класифрікацію ігор за типами компетенцій: ігри фронетичні, ігри лексичні, ігри граматичні, ігри мовленневі, ігри рольові [2, с. 223].

У дослідженнях Л. Крючкової зазначено, що ігрова діяльність виконуе такі фрункції:

- навчальну фрункцію - розвиток загальнонавчальних умінь та навичок, таких як пам'ять, увага, сприйняття інформації різноманітної модальності; розвиток навичок володіння іноземною мовою;

- розважальну фрункцію - створення приємної атмосфери на заняттях, перетворення уроку на захопливу подорож;

- комунікативну фрункцію - об’днання студентів, встановлення емоційних контактів;

- релаксаційну фрункцію - зняття емоційної напруги, викликаного навантаженням на центральну нервову систему під час інтенсивного навчання;

- психотехнічну фрункцію - формування навичок підготовки свого фізіологічного стану до більш ефрективної діяльності, перебудови психіки для засвоєння більших обсягів індрормащії [6, с. 70].

Отже, виділимо наступні особливості гри, що сприяють розвитку комунікативних навичок у студентів:

1. Ігри допомагають підвищити інтерес студентів, зробити процес навчання більш плідним. Закріплення наявних і отриманих нових мовленневих навичок і вмінь в ігровій діяльності проходить більш активно.

2. Гра створює невимушену, наближену до ситуації реального спілкування атмосферу, в якій найповніше реалізуеться комунікативний потенціал студентів і таким чином руйнуеться мовний бар'ер.

3. В іграх значно збільшується об'єм мовленнєвої діяльності студентів. Крім того, робота в парах або спільні відповіді допомагають подолати страх зробити помилку.

4. Під час гри роль викладача - це переважно роль спостерігача. Викладач перебуває поміж групами, фріксує помилки, щоб пізніше розібрати їх. Таким чином, гра може стати хорошим діагностичним полем для викладача [1, с. 102].

Ігри в навчанні іноземної мови виконують велику роль, дозволяючи студентові на занятті не тільки вивчати мовні закони чи правила, але і використовувати мову для задоволення комунікативних потреб. Часто студентські групи одномовні, тобто студенти можуть порозумітися рідною мовою, не використовуючи іноземної, яку вивчають, а комунікативні ситуації настільки тематично обмежені, що не дають студентам розширити межі комунікативної компетенції. Тому ігри - простий і ефрективний спосіб наблизити навчальний процес до реальної мовної стихії таким чином, щоб комунікативні ситуації не були сприйняті ними як неприродні і непотрібні в реальному спілкуванні, а навпаки - стимулювали до розвитку мовленневих навичок.
Дослідження вчених-педагогів свідчать, що ігрові методи і форми навчання сприяють формуванню не лише спеціальних умінь і навичок, а й загальнонавчальних способів розумових дій планувальних, мисленневих, сприяючи розвиткові самокерувальних механізмів особистості [12].

Наведемо декілька прикладів використання ігор на заняттях 3 української мови як іноземної. Наприклад, рольова гра дає змогу відтворити будь-яку ситуацію в "ролях», спонукає студентів до психологічної переорієнтації. Такий метод інтенсифрікуе розумову працю, сприяє швидкому і глибокому засвоєнню навчального матеріалу. У процесі рольової гри розкривається інтелект студента; під зміни типу міжособистісних стосунків студент долає психологічний бар'єр спілкування. Наприклад, під час гри «Відвідування театру» студенти демонструють, як вони збираються в театр, як купують білети, що бачать і відчувають. А далі «глядачі» перетворюються в «акторів» і починають грати ролі 3 попередньо прочитаного тексту «Перший раз у театрі». Студенти в іграх мімікою, жестами, рухами передають різний емоційний стан персонажів, навчаються передавати інтонацією і силою голосу ігрові образи. Усе це допомагає оволодівати іноземною мовою, спілкуватись у різноманітних життевих ситуаціях. Жест і міміка - це одні із видів ключів пам'яті поряд 3 мелодією, ритмом, римуванням, мнемонікою, тобто технікою запам'ятовування [2, с. 220]. Ключами пам'яті $є$ також різноманітні коментарі, наочність. Щоб запам'ятати, треба багато разів повторити, а щоб з'явились навички, треба багато разів здійснити мовленневі дії, тобто мотивовано вжити ту чи іншу фрразу. Така мотивація легко виникає у грі. Залишається тільки завчити потрібний мовний матеріал в іграх.

Ігри з використанням схем, планів, карт є провідним видом діяльності під час вивчення дієслів руху. Наприклад, гра «Як знайти скарб»: використовуючи ілюстровану карту-схему (рис. 1), студенти «шукають скарб». Мета гри - вживання дієслів руху з префіксами, вдосконалення комунікативної компетенції.

Можна поділити студентів на групи по 3 особи. Спочатку один студент, який залишається на місці і не бере участі у пошуку, але добре знає маршрут на карті, пояснюе іншому як дійти до мети.

Наприклад, перший маршрут: «Щоб знайти скарб, треба зайти в музей і взяти ключ від скрині зі скарбом. Потім треба вийти з музею, пройти під аркою, перейти через міст, обійти карусель, перейти шосе, перейти через струмок, пройти повз ялини і будинку лісника та дійти до високої гори. Там ти повинен зупинитися і чекати сигналу». Таким чином, цей студент повторює фрорми інфінітива префіксальних дієслів руху. Можна дати завдання другому студенту пояснити весь маршрут, використовуючи форму дієслова майбутнього часу. Наприклад: «Спочатку ти зайдеш в музей, візьмеш там ключ від скрині, вийдеш із музею, перейдеш під аркою, пройдеш через міст, потім обійдеш карусель, перейдеш шосе, потім перейдеш через струмок, пройдеш повз ялини i будинку лісника, дійдеш до високої гори і будеш чекати сигналу». 


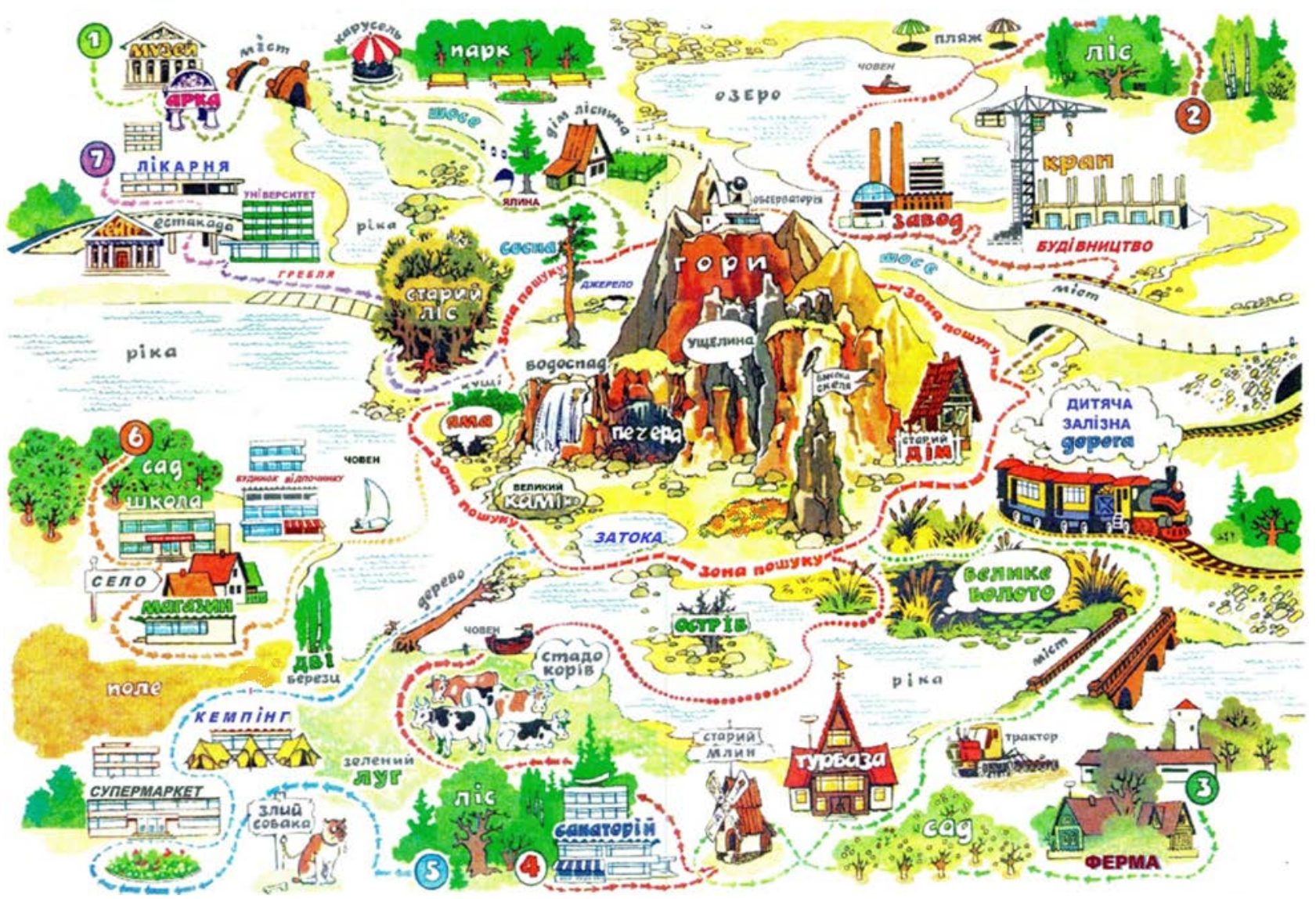

Рис. 1. Карта-схема «Як знайти скарб»

Джерело: розроблено автором Плотніковою Т.О.

Третій студент «йде» за вказаним маршрутом, коментуючи кожну свою дію: «Я заходжу в музей, беру ключ від скрині зі скарбом, виходжу з музею, проходжу під аркою, переходжу через міст, обходжу карусель, переходжу шосе, переходжу через струмок, проходжу повз ялини і будинку лісника, доходжу до високої гори і чекаю сигналу». Інший студент вживае ці діеслова у формі теперішнього часу недоконаного виду. А наступний студент, наприклад, може прокоментувати маршрут, використовуючи форму діеслова минулого часу: «Ахмед зайшов в музей, взяв там ключ від скрині, вийшов із музею, пройшов під аркою, перейшов через міст, обійшов карусель, перейшов шосе, потім перейшов через струмок, пройшов повз ялини і будинку лісника і дійшов до високої гори і чекав сигналу». Таким чином, студент вживае діеслова руху у формі минулого часу доконаного виду.

Отже, студенти багато разів здійснюючи мовленневі дії, «пройшли» один і той же маршрут, і вживали кожне діеслово у формі інфінітива, майбутнього, теперішнього та минулого часу. Навіть якщо на початку гри виникають труднощі, то після «проходження» багатьох (у нашому випадку їх сім) різних маршрутів за ілюстрованою картою-схемою, студенти правильно вживають діеслова руху з префіксами в різних часових формах: 1) музей - арка - карусель - шосе - ялина - висока гора; 2) ліс - пляж - озеро - човен завод - міст - висока гора; 3) ферма - сад - турбаза - міст - дитяча залізна дорога - висока гора;
4) ліс - санаторій - череда корів - човен - острів висока гора; 5) ліс - злий собака - кемпінг - дві берези - ріка - висока гора; 6) сад - школа - магазин - ріка - висока гора; 7) лікарня - естакада університет - старий ліс - висока гора. Виграє той, хто перший правильно утворить відповідні форми дієслів руху з префріксами і швидше «дійде» до високої гори.

Ігри 3 використанням схем також сприяють автоматизації мовленневих дій і є потрібними в реальному спілкуванні.

Наприклад, гра «Як я їду в університет», яку можна провести, використовуючи схему харківського метро (рис. 2).

Студенти пишуть і розповідають коротку історію про свою дорогу в університет (5-6 речень), при цьому пропускаючи окремі деталі: «Я живу далеко від метро. Спочатку я їду на тролейбуci № 1 до станщії «Палац спорту» (червона лінія). Від станції «Палац спорту» я їду до станції "Спортивна». На станції "Спортивна» я переходжу на Олексіївську лінію (зелену). Від станції метро «Метробудівників» я їду до станції «Архітектора Бекетова». Потім студенти в парах обмінюються текстами і вписують пропущені деталі та розповідають, як хто їде чи йде в університет. Наприклад, Ахмед і Хасан живуть в гуртожитку № 6 , який розташований недалеко від станщії метро «Ботанічний сад». Хішам і Самір живуть в гуртожитку № 1 , який розташований недалеко від станції метро "Пушкінська". Сабріна і Віам орендують квартиру біля станції метро «Акаде- 


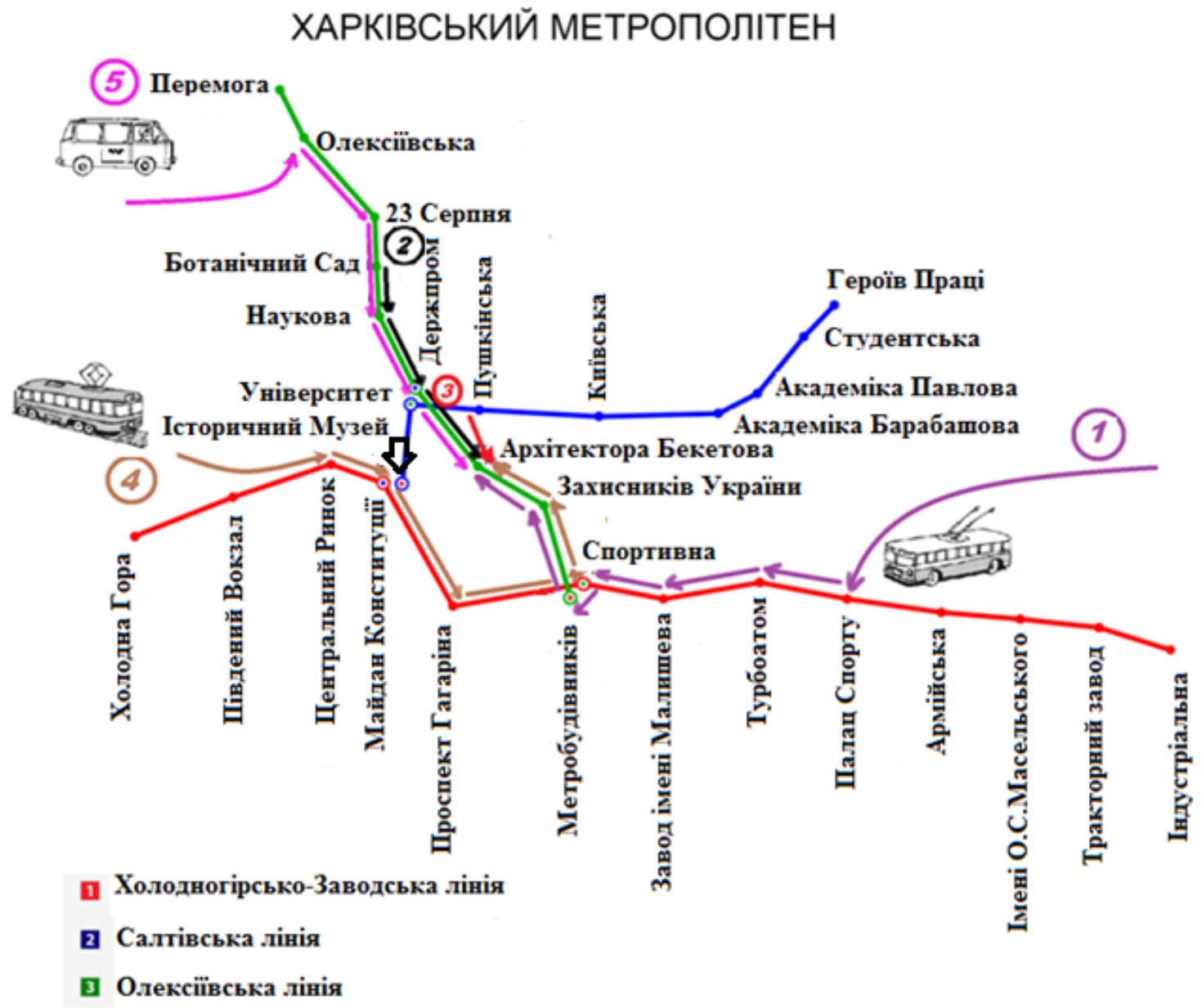

Рис. 2. Схема харківського метро

Джерело: розроблено автором Плотніковою Т.О.

міка Павлова» (синя лінія). Студенти отримують задоволення від спілкування й обміну думками, не хвилюються за можливі помилки. Жваве зацікавлення цією темою сприяе розвитку впевненості у собі і поліпшенню комунікативних навичок студентів.

Таким чином, регулярне проведення комунікативних ігор сприяє оволодінню навичками спілкування, зближуе студентів загальною для всіх діяльністю, дає їм новий мовленневий досвід і уміння. Щоб відтворити фонетичну систему чужої мови, треба бути комунікабельним, щоб на початковому етапі вивчення говорити на ній. Займаючись іноземною мовою, студент збагачує себе новими знаннями і вміннями та одночасно вдосконалює себе як особистість.

Використання мовленнєвих ігор дає такі переваги: реальний розвиток розмовних навичок і можливість безпосереднього спілкування; досягнення свого власного рівня у вивченні мови, додаткову практику слухання разом із різною кількістю ак- центів, можливість навчатися один від одного. Викладач може простежити прогрес студентів.

Висновки 3 даного дослідження. Проблема формування комунікативної компетенції іноземних студентів є однією з найважливіших під час занять з української мови як іноземної. Формування у іноземних студентів комунікативних навичок вимагає від них вміння вступати в контакт 3 носіями мови.

З’ясовано, що у формуванні комунікативної компетенції студентів під час вивчення української мови найкращих результатів можна досягти, застосовуючи ігрові методи. Під час гри у студентів формуються ті уміння та навички, які впливатимуть на їх адаптацію у мовному середовищі, на розвиток їх творчого потенціалу. Такі нестандартні форми педагогічної взаємодії сприяють фрормуванню соціально активної, комунікативної особистості і є засобом успішного формування комунікативної компетентності майбутніх фрахівців.

\section{Список літератури:}

1. Азарина Л.Е. Игры на уроках РКИ. Вестник ЦМО МГУ. 2009. № 3. С. 102-109.

2. Акишина А.А., Каган О.Е. Учимся учить: для преподавателя русского языка как иностранного. Москва, 2002.256 с.

3. Выготский Л.С. Игра и ее роль в психологическом развитии ребенка. Вопросы психологии. 1966. № 6. С. $62-77$.

4. Эльконин Д. Психология игры. Москва, 1999. 360 с.

5. Срмоленко С.Я. Формування комунікативної компетенції у лінгводидактиці. Українська лова $і$ література в школі. 2007. № 3. С. 42-46. 
6. Крючкова Л.С., Мощинская Н.В. Практическая методика обучения русскому языку как иностранному : учеб. пособие. Москва: Наука, 2013. 280 с.

7. Ланге К. Карл Гроос: ігри людей. Йена. ЕСНО. 1900. № 22. C. 48-54. URL: http://echo.mpiwgberlin.mpg.de/ ECHOdocuView?url=/permanent/vlp/lit31138/index.meta (дата звернення: 24.04.2020).

8. Мармаза O.I. Можливості та особливості реалізації ігрових технологій у навчальному процесі вищої школи : навчально-методичний посібник. Харків, 2002. 114 с.

9. Палінська О. Корекція помилок студентів у курсі української мови як іноземної. Теорія $і$ практика викладання украӥнської мови як інозелної : зб. наук. праць. Львів, 2011. Вип. 6. С. 204-210.

10. Пометун О. І., Пироженко Л.В. Сучасний урок. Інтерактивні технології навчання. Київ : АСК, 2005.197 с.

11. Про Вищу освіту: Закон України від 1 липня 2014. № 1556-VII / Верховна Рада України. URL: https://zakon.rada.gov.ua/laws/show/1556-18 (дата звернення: 01.04.2020).

12. П'яст Н.И. Ігри як один із методів навчання на заняттях з української мови Гуланізл та освіта : праці 10 міжнар. наук.-практ. конф. 2010. URL: http://conf.vntu.edu.ua/humed/2010/txt/Pyast_Gorchynska.php (дата звернення: 24.04.2020).

13. Хуторской А.В. Компетентностный подход в обучении. Москва, 2013. 73 с.

\section{Referenses:}

1. Azarina, L.E. (2009). Igry na urokakh RKI [Games at RCT lessons]. Vestnik TsMO MGU, no. 3, pp. $102-109$.

2. Akishina, A.A., \& Kagan, O.E. (2002). Uchimsya uchit': dlya prepodavatelya russkogo yazyka kak inostrannogo [Learning to learn: for a teacher of Russian as a foreign language]. Moskow: Rus. yaz. (in Russian)

3. Vygotskiy, L.S. (1966). Igra i ee rol' v psikhologicheskom razvitii rebenka [The game and its role in the psychological development of the child]. Voprosy psikhologii, no. 6, pp. 62-77.

4. El'konin, D. (1999). Psikhologiya igry [Psychological games]. Moskow: Vlados. (in Russian)

5. Yermolenko, S.Ya. (2007). Formuvannia komunikatyvnoi kompetentsii u linhovodydaktytsi [Formation of communicative competence in linguistics]. Ukrainska mova i literatura $v$ shkoli, no. 3, pp. 42-46

6. Kryuchkova, L.S., \& Moshchinskaya, N.V. (2013). Prakticheskaya metodika obucheniya russkomu yazyku kak inostrannomu [A practical method for teaching russian as a foreign language]. Moskow: Nauka. (in Russian)

7. Lanhe, K. (1900). Karl Hroos: ihry liudei [Karl Groos: people games] Zhurnal psikhologii i fiziologii organov chuvstv (electronic journal), no. 22, pp. 48-54. Available at: http://echo.mpiwgberlin.mpg.de/ECHOdocuView?url=/ permanent/vlp/lit31138/index.meta (accessed 24 April 2020).

8. Marmaza, O.I. (2002). Mozhlyvosti ta osoblyvosti realizatsii ihrovykh tekhnolohii u navchalnomu protsesi vyshchoi shkoly: navchalno-metodychnyi posibnyk [Features and features of the introduction of game technologies in the educational process of higher education]. Kharkiv. (in Ukrainian)

9. Palinska, O. (2011). Korektsiia pomylok studentiv u kursi ukrainskoi movy yak inozemnoi [Correcting students' mistakes in the Ukrainian language course as a foreign language]. Teoriya $i$ praktyka vykladannya ukrayins'koyi movy yak inozemnoyi: zb. nauk. prats'. Lviv, vol. 6, pp. 204-210.

10. Pometun, O.I., \& Pyrozhenko, L.V. (2005). Suchasnyi urok. Interaktyuni tekhnolohii navchania [Modern lesson. Interactive learning technologies]. Kyiv: ASK. (in Ukrainian)

11. Pro Vushchu osvitu: Zakon Ukrayiny vid 1 lypnya 2014. No. 1556-VII. Available at: https://zakon.rada.gov.ua/ laws/show/1556-18 (accessed 1 April 2020).

12. P'iast, N.Y. (2010). Ihry yak odyn iz metodiv navchannia na zaniattiakh z ukrainskoi movy [Games as one of the methods of teaching in the Ukrainian language]. Humanizm ta osvita (elektronik journal). Available at: http://conf.vntu.edu.ua/humed/2010/txt/Pyast_Gorchynska.php (accessed 24 April 2020).

13. Khytorskoy, A.V. (2013). Kompetentnostnyy podkhod v obychenii [Competency-based approach in training: a scientific and methodological manual]. Moskow. (in Russian) 